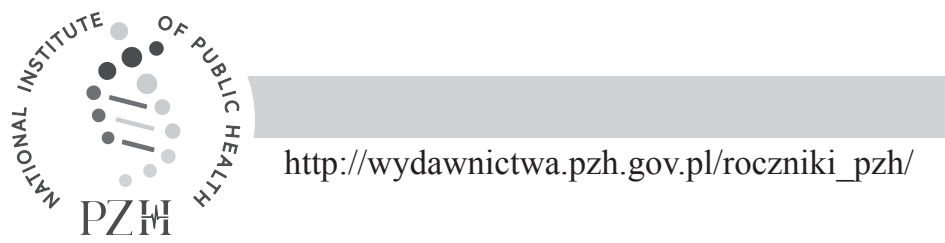

\title{
DIET AND NUTRITIONAL STATUS OF ELDERLY PEOPLE DEPENDING ON THEIR PLACE OF RESIDENCE
}

\author{
Anna Bogacka ${ }^{I}$,Angelika Heberlej ${ }^{I}$, Alicja Usarek ${ }^{l}$, Joanna Okoniewska ${ }^{I}$ \\ ${ }^{1}$ Department of the Fundamentals of Human Nutrition, Faculty of Food Sciences and Fisheries, \\ West Pomeranian University of Technology in Szczecin, Poland
}

\begin{abstract}
Background. The main problems in nutrition among elderly people are insufficient consumption of high energy protein and deficiencies in vitamins and minerals. Obesity or malnutrition in this age group is also common. The character of the diet of the elderly is affected by many factors, including the place of residence.

Objective. The aim of this work was to compare the diet and nutritional status of elderly people living in nursing homes and in their family homes in West Pomeranian Voivodeship region.

Material and methods. The study was performed among 48 citizens of Drawsko Pomorskie (DP) and 79 residents of Nursery Home (NH) in Żabów. For the study we used a questionnaire containing questions about anthropometric data which served to assess nutritional state. The assessment of diets of the citizens of Drawsko Pomorskie was performed based on the menus collected using a 24-hour diet recall. Energy and nutritional value of the diets of NH residents were assessed on the basis of decade menus. Obtained results were compared to current recommendations.

Results. Two examined groups comprised of both underweight and obese people. The residents of NH in Żabów consumed more energy, protein, fat, cholesterol and carbohydrates, whereas people from DP - more dietary fibre. Diets of the citizens of DP were characterized by excessive consumption of sodium, phosphorus, iron, zinc, copper and vitamins: $\mathrm{A}_{2} \mathrm{~B}_{2}, \mathrm{~B}_{6}, \mathrm{~B}_{12}$ and niacin, and insufficient consumption of potassium, calcium, magnesium and vitamins: D, E, C and folates. The diets of people living in family homes were excessive in sodium, phosphorus, iron, copper and vitamins: $\mathrm{A}, \mathrm{B}_{1}, \mathrm{~B}_{6}, \mathrm{C}$ and niacin, and contained too little calcium, magnesium and vitamins D, E and folates.

Conclusion. It was shown that the place of residence of examined people affected their diets and nutritional status. Both in case of people living in NH and in family homes there was a risk of underweight and obesity, which could be affected by improper way of nutrition.
\end{abstract}

Keywords: nutrition, nutritional state, elderly people, nursing home

\section{STRESZCZENIE}

Wprowadzenie. Do głównych problemów odżywiania osób w starszym wieku należą: niedostateczna ilość spożywanego wysokoenergetycznego białka, niedobory witaminowe i mineralne. Powszechna jest również otyłość lub niedożywienie występująca w tej grupie wiekowej. Na charakter i sposób odżywiania się osób starszych wpływa wiele czynników m. in. miejsce zamieszkania.

Cel badań. Celem pracy było porównanie sposobu żywienia oraz stanu odżywienia osób starszych zamieszkałych w domu pomocy społecznej oraz w warunkach domowych na terenie województwa zachodniopomorskiego.

Material i metody. Badania przeprowadzono wśród 48 mieszkańców Drawska Pomorskiego (DP) oraz 79 pensjonariuszy Domu Pomocy Społecznej (DPS) w Żabowie. Do badań użyto ankiety zawierającej dane antropometryczne, które posłużyły do oceny stanu odżywienia. Oceny sposobu żywienia mieszkańców Drawska Pomorskiego dokonano w oparciu o jadłospisy zebrane metodą wywiadu 24-godzinnego. Natomiast wartość energetyczną i odżywczą diet pensjonariuszy DPS oceniono na podstawie otrzymanych jadłospisów dekadowych. Otrzymane wyniki porównano z obowiązującymi normami. Wyniki. W obu badanych grupach były osoby z niedowagą oraz nadmierną masą ciała. Pensjonariusze DPS w Żabowie spożywali więcej energii, białka, tłuszczu, cholesterolu oraz węglowodanów, natomiast osoby z DP - błonnika pokarmowego. Diety mieszkańców DPS charakteryzowała nadmierna ilość sodu, fosforu, żelaza, cynku, miedzi oraz witamin: A, $\mathrm{B}_{2}, \mathrm{~B}_{6}, \mathrm{~B}_{12}$ i niacyny, a niewystarczająca: potasu, wapnia, magnezu oraz witamin: D, E, C i folianów. Diety osób zamieszkałych w warunkach domowych miały zbyt dużo sodu, fosforu, żelaza, miedzi oraz witamin: A, B , B, C i niacyny, a zbyt mało wapnia i magnezu oraz witamin: D, E i folianów.

Corresponding author: Anna Bogacka, Department of the Fundamentals of Human Nutrition, Faculty of Food Sciences and Fisheries, West Pomeranian University of Technology in Szczecin, ul. Papieża Pawła VI 3, 71-459 Szczecin, tel. +48 914496519, fax. +48 914496516, e-mail: anna.bogacka@zut.edu.pl

(C) Copyright by the National Institute of Public Health - National Institute of Hygiene 
Wnioski. Wykazano, że miejsce zamieszkania osób badanych ma wpływ na ich sposób żywienia i stan odżywienia. Zarówno u osób mieszkających w DPS, jak i domach wystąpiło ryzyko niedowagi i nadmiernej masy ciała, do których mógł przyczynić się nieprawidłowy sposób żywienia.

Słowa kluczowe: odżywianie się, stan odżywienia, osoby starsze, dom pomocy społecznej

\section{INTRODUCTION}

Ageing is a natural, irreversible process constantly happening to us for our whole adult life. Currently observed demographic changes are mainly caused by the development in medicine, improvement in the level of hygiene and vaccination but also by the decrease in fertility and birth rate [15]. Increasing percentage of elderly people, not only in Poland but throughout the world [12], results in growing interest in this social group among the researchers. Gerontology allows for a better care for the elderly, improves their life conditions and thus makes their future more decent.

One of the characteristics of this age group is multiple morbidities. Elderly people often suffer from such diseases as cardiovascular diseases, diabetes (especially type 2), tumours, various types of digestive problems (constipation, flatulence, eating disorder), urinary incontinence, but also insomnia, depression, dementia and hearing and sight disorders [15]. Considering that many of these diseases are diseases of affluence, one should put special attention to their prevention, which includes appropriate nutrition enabling to maintain a good physical and mental condition [2].

Proper feeding of elderly people is challenging due to gastric problems, economical situation or longstanding bad habits. Very important factors affecting the diets of the elderly are psychosocial factors, of which the most important is everyday stress. Emotional support of the family and surrounding people, satisfaction from life and the feeling of control over one's life are very important factors, which can significantly contribute to the improvement of last years of life [15].

Therefore, there is a need to develop and run educational programs directed to this social group which include proper nutrition [5]. One of them is a strategy developed by WHO, referring to the diet, physical activity and health, which establishes the means of implementation and evaluation of the activities promoting a healthy lifestyle [10]. The access to educational programs is determined by e.g. the place of residence of an elder, which will influence the diet and nutritional status. In this study we compared the diet and nutritional status of elderly people living in nursing home and in their family homes in West Pomeranian Voivodeship.

\section{MATERIAL AND METHODS}

The study was performed among the citizens of Drawsko Pomorskie (DP) and the residents of Nursing House (NH) in Żabów. The total number of the participants was 127, including 48 elders living in their family homes and 79 in NH. The details on the size of examined groups are presented in Table 1.

Table 1. Size of examined groups with respect to age

\begin{tabular}{|c|c|c|c|c|c|c|c|c|c|c|c|c|}
\hline \multirow{3}{*}{ Age interval } & \multicolumn{6}{|c|}{ Residents of NH in Żabów } & \multicolumn{6}{|c|}{ Citizents of Drawsko Pomorskie } \\
\hline & \multicolumn{2}{|c|}{$\begin{array}{c}\text { Women } \\
n=39\end{array}$} & \multicolumn{2}{|c|}{$\begin{array}{c}\text { Men } \\
\mathrm{n}=40\end{array}$} & \multicolumn{2}{|c|}{$\begin{array}{c}\text { Total } \\
\mathrm{n}=79\end{array}$} & \multicolumn{2}{|c|}{$\begin{array}{l}\text { Women } \\
\mathrm{n}=33\end{array}$} & \multicolumn{2}{|c|}{$\begin{array}{c}\text { Men } \\
n=15\end{array}$} & \multicolumn{2}{|c|}{$\begin{array}{c}\text { Total } \\
\mathrm{n}=48\end{array}$} \\
\hline & $\mathrm{n}$ & $\%$ & $\mathrm{n}$ & $\%$ & $\mathrm{n}$ & $\%$ & $\mathrm{n}$ & $\%$ & $\mathrm{n}$ & $\%$ & $\mathrm{n}$ & $\%$ \\
\hline $51-65$ & 6 & 15.4 & 17 & 42.5 & 23 & 29.1 & 0 & 0.0 & 0 & 0.0 & 0 & 0.0 \\
\hline $66-75$ & 6 & 15.4 & 14 & 35 & 20 & 25.3 & 20 & 60.6 & 8 & 53.3 & 28 & 58.3 \\
\hline$>75$ & 27 & 69.2 & 9 & 22.5 & 36 & 45.6 & 13 & 39.4 & 7 & 46.7 & 20 & 41.7 \\
\hline
\end{tabular}

The participants of the study in the authors' questionnaire gave the basic anthropometric data, which were used to assess nutritional status. Quantitative analysis of daily food ratios (DFR) among the residents of Drawsko Pomorskie was performed based on the menus collected using a 24-hour dietary recall. The "Album of photographs of produce and meals" [29] was used to estimate the size of food portions. Energy and nutritional value of DFRs of the residents of the $\mathrm{NH}$ was assessed based on obtained decade menus. The contents of energy, basic nutrients, vitamins and minerals in the diets was calculated using a computer software Dieta 5.D (Institute of Food and Nutrition, Warsaw). Obtained results were compared with current standards at the level of estimated average requirement of the group (EAR) or adequate intake (AI) [13]. Required standard values for energy and particular components of the diet were established using weighted average method. Supplementation was not taken into consideration in the calculations. 
All the results were statistically analysed using Statistica v. 13.0 (Statsoft). Due to the fact that the characteristics did not have normal distribution the significance of differences was calculated using a nonparametric Mann-Whitney $\mathrm{U}$ test. The significance level was $\mathrm{p}<0.05$.

\section{RESULTS}

BMI (Body Mass Index) was calculated based on obtained information concerning the weight and height and enabled the assessment of nutritional status of the examined. The average value of BMI of elderly people living in their family homes was $28.1 \pm 3.8 \mathrm{~kg} /$ $\mathrm{m}^{2}$ and was slightly higher than for the residents of $\mathrm{NH}$ $\left(26.7 \pm 5.0 \mathrm{~kg} / \mathrm{m}^{2}\right)$.The analysis of nutritional status of the elderly with respect to their place of residence is presented in Table 2.

According to WHO classification, every third person from Drawsko Pomorskie had proper body weight, which was a slightly lower percentage than in case of the examined residents of NH. The majority of examined elders were overweight or obese $(71 \%$ and $60 \%$, respectively). Taking into consideration the classification of Queensland Government [20], almost every sixth citizen of DP (17\%) and every third resident of $\mathrm{NH}(33 \%)$ was underweight. Using QG interpretation, almost $45 \%$ of the examined people has a proper body weight and excessive weight was noted in every fifth person living in $\mathrm{NH}(20 \%)$ and in $42 \%$ people living in family homes. Obesity was not observed. Detailed information is presented in Table 2.

Table 2. Interpretation of BMI of examined people according to WHO and Queensland Government (QG) [23]

\begin{tabular}{|c|c|c|c|c|c|c|}
\hline & \multicolumn{3}{|c|}{ WHO } & \multicolumn{3}{c|}{ QG } \\
\cline { 2 - 7 } & $\begin{array}{c}\text { BMI range } \\
\left(\mathrm{kg} / \mathrm{m}^{2}\right)\end{array}$ & $\begin{array}{c}\text { people living in } \\
\text { family homes } \\
(\%)\end{array}$ & $\begin{array}{c}\text { people living } \\
\text { in NH } \\
(\%)\end{array}$ & $\begin{array}{c}\text { BMI range } \\
\left(\mathrm{kg} / \mathrm{m}^{2}\right)\end{array}$ & $\begin{array}{c}\text { people living in } \\
\text { family homes } \\
(\%)\end{array}$ & $\begin{array}{c}\text { people living } \\
\text { in NH } \\
(\%)\end{array}$ \\
\hline Underweight & $<18.5$ & 0 & 3.0 & $<23$ & 17.0 & 33.0 \\
\hline Normalweight & $18.5-24.99$ & 29.0 & 37.0 & $24-30$ & 42.0 & 47.0 \\
\hline Overweight & $25.00-29.99$ & 29.0 & 37.0 & $>30$ & 42.0 & 20.0 \\
\hline Obesity & $>30$ & 42.0 & 23.0 & - & - & - \\
\hline
\end{tabular}

The analysis of examined menus enabled to compare the average consumption of energy, basic nutrients, minerals and vitamins among the residents of $\mathrm{NH}$ and citizens of DP. Obtained results and realization of the norms are presented in Tables 3-4.

The residents of $\mathrm{NH}$ consumed significantly more energy $(2036.3 \pm 134.8 \mathrm{kcal})$ than people living in family homes $(1602.9 \pm 519.1 \mathrm{kcal})$, which contributed to higher percentage of norm realization $(92,9 \%$ and $79.8 \%$, respectively). Among the residents of $\mathrm{NH}$, a significantly higher consumption of all analysed nutrients was observed, with the exception of dietary fibre, whose intake was slightly higher for citizens of DP, but it was within the standards (Table 3 ).

Table 3. Average consumption of energy and nutrients among examined people $(n=127)$

\begin{tabular}{|l|c|c|c|c|}
\hline \multirow{2}{*}{ Component } & \multicolumn{2}{|c|}{ NH $(\mathrm{n}=79)$} & \multicolumn{2}{c|}{ DP $(\mathrm{n}=48)$} \\
\cline { 2 - 5 } & Average \pm SD & \% norm realization & Average \pm SD & \% norm realization \\
\hline Energy $[\mathrm{kcal}]^{*}$ & $2036.3 \pm 134.8$ & 92.9 & $1602.9 \pm 519.1$ & 79.8 \\
\hline Protein $[\mathrm{g}]^{*}$ & $75.7 \pm 8.1$ & 152.3 & $59.5 \pm 15.5$ & 117.9 \\
\hline Fat $[\mathrm{g}]^{*}$ & $79.1 \pm 11.5$ & 108.2 & $51.6 \pm 20.9$ & 77.2 \\
\hline Cholesterol $[\mathrm{mg}]^{*}$ & $313.6 \pm 91.4$ & 104.5 & $213.2 \pm 110.8$ & 71.0 \\
\hline Total carbohydrates $[\mathrm{g}]^{*}$ & $273.1 \pm 21.8$ & 210.1 & $243.1 \pm 108.2$ & 187 \\
\hline Dietary fibre $[\mathrm{g}]$ & $19.5 \pm 3.3$ & 94.1 & $20.5 \pm 9.0$ & 102.3 \\
\hline
\end{tabular}

*statistically significant differences at the level of $p<0.05$

The residents of $\mathrm{NH}$ consumed, on average, higher amounts of calcium, phosphorus, iron, zinc and copper. On the other hand, the diets of the citizens of DP were characterized by higher contents of sodium and potassium. In case of sodium the differences were statistically significant (Table 4).
The analysis of vitamins contents in daily food ratios showed that the realization of norms among the participants of the study differed significantly with respect to vitamins $\mathrm{E}, \mathrm{B}_{2}, \mathrm{~B}_{12}, \mathrm{C}$ and folates. The residents of $\mathrm{NH}$ consumed significantly more riboflavin and cobalamin, whereas the people living in family homes - more vitamin $\mathrm{E}$, folates and vitamin $\mathrm{C}$ (Table 4). 
Table 4. Average consumption of minerals and vitamins among examined people $(n=127)$

\begin{tabular}{|c|c|c|c|c|}
\hline \multirow[b]{2}{*}{ Component } & \multicolumn{2}{|c|}{$\mathrm{NH}(\mathrm{n}=79)$} & \multicolumn{2}{|c|}{$\mathrm{DP}(\mathrm{n}=48)$} \\
\hline & Average $\pm \mathrm{SD}$ & $\begin{array}{l}\% \text { norm } \\
\text { realization }\end{array}$ & Average \pm SD & $\%$ norm realization \\
\hline Sodium $[\mathrm{mg}]^{*}$ & $2224.6 \pm 319.6$ & 172.8 & $2787.8 \pm 979.1$ & 232.3 \\
\hline Potassium [mg] & $2750.3 \pm 488.0$ & 78.6 & $3505.9 \pm 2126.5$ & 100.2 \\
\hline Calcium $[\mathrm{mg}]^{*}$ & $665.7 \pm 180.5$ & 69.7 & $446.4 \pm 181.9$ & 44.6 \\
\hline Phosphorus [mg]* & $1212.3 \pm 155.4$ & 209.0 & $1129.4 \pm 557.0$ & 194.7 \\
\hline Magnesium [mg] & $260.6 \pm 52.0$ & 84.6 & $261.4 \pm 118.3$ & 89.6 \\
\hline Iron $[\mathrm{mg}]^{*}$ & $12.1 \pm 5.1$ & 201.3 & $9.9 \pm 4.9$ & 165.0 \\
\hline Zinc $[\mathrm{mg}]^{*}$ & $10.3 \pm 1.5$ & 127.1 & $8.3 \pm 2.6$ & 108.8 \\
\hline Copper $[\mathrm{mg}]^{*}$ & $1.1 \pm 0.2$ & 153.2 & $0.96 \pm 0.4$ & 137.8 \\
\hline $\operatorname{Vitamin} \mathrm{A}[\mu \mathrm{g}]$ & $1429.1 \pm 2121.1$ & 252.6 & $852.4 \pm 525.8$ & 157.7 \\
\hline Vitamin $\mathrm{D}[\mu \mathrm{g}]$ & $2.5 \pm 1.8$ & 16.6 & $2.2 \pm 2.0$ & 14.9 \\
\hline Vitamin E [mg]* & $5.9 \pm 2.0$ & 65.0 & $7.6 \pm 3.3$ & 88.5 \\
\hline Thiamine [mg] & $1.1 \pm 0.2$ & 111.5 & $1.2 \pm 0.6$ & 122.7 \\
\hline Riboflavin [mg]* & $1.6 \pm 0.6$ & 162.3 & $1.1 \pm 0.3$ & 114.1 \\
\hline Niacin $[\mathrm{mg}]$ & $14.4 \pm 4.1$ & 124.9 & $19.9 \pm 14.3$ & 176.6 \\
\hline Vitamin $B_{6}[\mathrm{mg}]$ & $1.8 \pm 0.4$ & 133.9 & $1.9 \pm 0.7$ & 143.0 \\
\hline Folate $[\mu \mathrm{g}]^{*}$ & $140.9 \pm 27.8$ & 44.0 & $252.7 \pm 99.9$ & 79.0 \\
\hline Vitamin $\mathrm{B}_{12}[\mu \mathrm{g}]^{*}$ & $5.5 \pm 5.5$ & 272.5 & $2.2 \pm 2.0$ & 112.2 \\
\hline Vitamin C [mg]* & $32.0 \pm 15.2$ & 47.4 & $102.7 \pm 56.1$ & 158.7 \\
\hline
\end{tabular}

*statistically significant differences at the level of $\mathrm{p}<0.05$

Figure 1 shows the share of macronutrients $(A)$ and fatty acids (B) in energy supply. Among the examined people we observed small differences in the ratio of consumed nutrients. It was observed that in DFR of $\mathrm{NH}$ residents there was significantly higher percentage of energy from fat, which contributed to a lower intake of energy from carbohydrates in this group. The share of protein in energy supply was at a similar level in both examined groups. The residents from Żabów consumed the highest amounts of saturated fatty acids, which caused their higher intake in this group in comparison to the people living in family homes. On the other hand, the residents of Drawsko Pomorskie consumed less monounsaturated fatty acids and more polyunsaturated fatty acids than the residents of $\mathrm{NH}$.
A

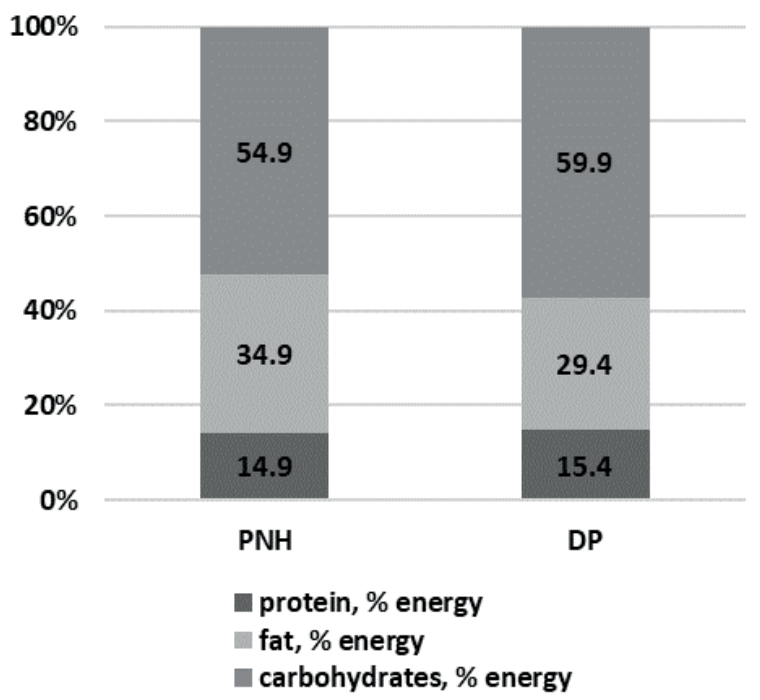

\section{B}

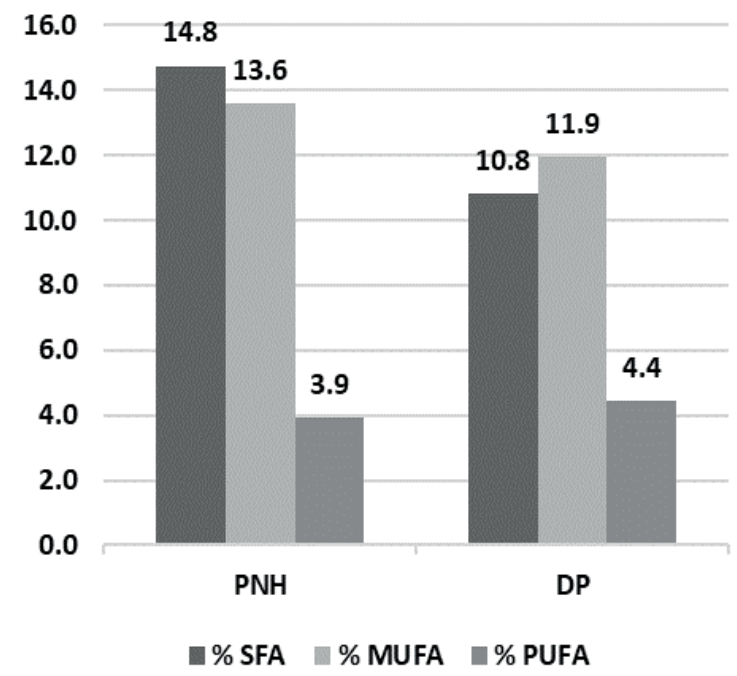

Fig. 1. Share of Energy from macronutrients (A) and fatty acids (B) in diets of the examined people. 


\section{DISCUSSION}

Agrowing tendency for the ageing of the population is currently observed worldwide. One of the main factors contributing to improvement in longevity has been a better medical care in recent years. Maintaining a proper nutritional status in older age will positively contribute to improvement in the quality of life, despite the presence of many diseases typical for that age. One of the key elements used to assess nutritional status is BMI [1]. In the publication of Queensland Government [20] we find the information that the classification proposed by WHO may be inadequate for elderly people. It was shown that the lowest mortality in a group of people aged above 65 occurs in people with BMI within the range $24-31 \mathrm{~kg} / \mathrm{m}^{2}$ and a separate classification for BMI of elderly people was proposed. Taking the above into consideration, in this study it was observed that almost half of the participants, irrespective of their place of residence, had appropriate value of BMI. In the publication of Ene-Margit and Kai [8], the results of the BMI index of older people from 17 European countries were collected, which showed a slightly higher percentage $(60 \%)$ of participants with BMI assessed as proper for the elderly. A slightly smaller percentage (41\%) of those with normal BMI was observed among nursing home residents in Nysa [3].

Too low body weight in case of the elderly $\left(\mathrm{BMI}<18.5 \mathrm{~kg} / \mathrm{m}^{2}\right)$ is definitely unfavourable for the health, because it can result in quicker occurrence of malnutrition. Malnutrition affects $12-61 \%$ of the residents of long-term care facilities [31]. Own study also showed a slightly higher percentage of underweight people among the residents of $\mathrm{NH}$ (3\% according to $\mathrm{WHO}$ and $33 \%$ according to $\mathrm{QG}$ ) in comparison with the people living in own homes ( $0 \%$ and $17 \%$, respectively). Although, in the studies of Zoloteńka-Synowiec et al. [32] among residents of nursing homes in Nysa, the percentage of people with underweight was 16.4 (15.7\% in women and $20 \%$ in men).

Properly balanced diet is one of the crucial factors to maintain good health. With age the energetic demand of an organism decreases. Thus, in order to provide appropriate supply of all the necessary nutrients, the food consumed by elderly people should have high nutritional density, be low in calories and easy to digest $[26,29]$. In this study it was shown that the average energy value of a food ratio for people living in family homes was $1602.9 \mathrm{kcal}$ and was lower than for residents of $\mathrm{NH}$, which resulted in that the demand on energy was covered in only $79.8 \%$. Similar results were obtained by Sygnowska and Waśkiewicz [27], Różańska et al. [25], and Wtodarek and Gtabska [30] where the average energetic value of daily food ratios was $1756.6 \mathrm{kcal}, 1539.6 \mathrm{kcal}$ and $1830 \mathrm{kcal}$, respectively. Higher energy content in the home diets, but within the norm, were obtained in the study of Malczyk et al. [18] - $2066.2 \mathrm{kcal}$ and Wtodarek and Gtabska [30] - $2200 \mathrm{kcal}$. DFR of elderly people from nursing homes covered energy demand to a higher extend (93\% of norm realization). Different results were obtained by Grochowska-Niedworok et al. [11] and Gacek [9], where the residents food ratios supplied on average $2835.2 \mathrm{kcal}$ and $2746.9 \mathrm{kcal}$ a day, i.e. $141 \%$ and $118.5 \%$ of the norm.

The ratio of macronutrients in energy supply is very important in proper feeding of elderly people. This study has shown that both in case of people living in $\mathrm{NH}$ and in family homes the ratio of macronutrients was correct. In the study of Sygnowska and Waśkiewicz [27] the percentage of energy from protein was within the norm, but the energy from fat exceeded recommended values and the energy from carbohydrates was insufficient. Similar ratio of nutrients in energy supply was noted by Różańska et al. [25]. In the study of Catyniuk et al. [3] a lower percentage of energy from protein and normal from fats and carbohydrates has been demonstrated.

In this study, the average consumption of carbohydrates was within the range of 243-273 g/day, which supplied recommended $45-60 \%$ of the energy in both examined groups. Similar results were obtained by Grochowska-Niedworok et al. [11] and Orkusz and Gorla [21], who showed that ca. 55\% of energy came from carbohydrates. At the same time, higher consumption of total energy contributed to higher intake of this component in comparison with this study - from 338.8 to $385.8 \mathrm{~g} /$ day.

Dietary fibre plays a veryimportant role in the diet of the elderly and its consumption in the examined groups was appropriate. Similar results were obtained in the studies of Wtodarek and Gtabska [30].Lower supply of dietary fibrein home diets was observed in other studies $[3,18,27]$.

The process of ageing is connected to higher protein catabolism and muscle mass loss (sarcopenia). In the menus of both $\mathrm{NH}$ residents and DP citizens there was too high average amount of protein ( $152.3 \%$ and $117.9 \%$ of the norm, respectively). The diets of the residents of the Lower Silesian Nursing Home contained more protein by almost $9 \mathrm{~g}$, which, however, did not contribute to higher realization of the norm $(117.2 \%)$ than in this study [21]. In the study of Leszczyńska et al. [16], related to the feeding of the residents of nursing homes, the norms on protein content were also exceeded.

In this study it was shown that the consumption of total fat was at a correct level only among the residents of $\mathrm{NH}$ and amounted to $79.1 \mathrm{~g}$ /day, i.e. $108.2 \%$ of the norm. The citizens of DP consumed too little of this 
nutrient. Their DFRs realized the norm at the level of $77.2 \%$, which corresponded to $51.6 \mathrm{~g} / \mathrm{day}$. Such content of fat in the menus of examined people contributed to proper intake of cholesterol. Different results were noted in other studies, where the amounts of both total fat and cholesterol in home diets were too high and reached even $150 \%$ of the daily norm [18, 25, 27, 29]. The analysis of menus from $\mathrm{NH}$ in Krakow showed too much fat supply in both winter and summer [9].

The ratio of particular fatty acids in examined diets was not proper. Too high consumption of saturated fatty acids was observed, especially in the case of the residents of NH. Similar results were obtained by Leszczyńska et al. [16], who at the same time showed too low content of polyunsaturated fatty acids, which was in contradiction to the results obtained in this study, where their consumption was satisfactory. In other studies, the authors noted higher intake of polyunsaturated fatty acids, which delivered on average $9.4 \%$ of the energy [11].

The analysis of minerals and vitamins contents in examined diets showed numerous irregularities.

Excessive supply of sodium together with insufficient intake of potassium in elderly people may contribute to cardiovascular diseases, including high blood pressure [26], arrhythmia, renal impairment, disorders in sensorimotor excitation and in acid/base balance $[18,22]$.

In this study, too high intake of sodium was noted in both groups $(172.8 \%$ and $232.2 \%$ of the norm. Moreover, the diets of $\mathrm{NH}$ residents contained too low amounts of potassium (78.6\%). Higher content of sodium in DFR of elderly people in NH in Warsaw was shown by Włodarek and Gtabska [30]. Too high consumption of sodium was also confirmed by other authors $[4,18,22]$. Low intake of potassium observed in the group of $\mathrm{NH}$ residents is very common among the elderly, what was confirmed by the studies of Wtodarek and Gtabska [30]. On the other hand, Pieter [22] showed that potassium consumption was at a similar level to that in the group of people living in Drawsko Pomorskie examined by us.

This study revealed insufficient consumption of calcium - it was within the range from $446.4 \mathrm{mg}$ in the group from DP to $665.7 \mathrm{mg}$ for the residents of $\mathrm{NH}$, which covered the requirements in $44.6 \%$ and $69.7 \%$. Low intake of this element with the home diet was confirmed in numerous studies in various regions of Poland, where the realization of the norm was from 26 to $67 \%[19,22,25,26]$. Insufficient consumption of $\mathrm{Ca}$ may cause muscle cramps, heart disorders, development or worsening of osteoporosis and more frequent bone fractures. Moreover, proper intake of this element will have a positive effect on the regulation of the blood pressure [18]. In contrast, the calcium content in the analyzed menus met the standard on average in $59.2 \%$ in the diets of NH from Silesia [23].
Excessive supply of phosphorusin this social grouphas been observed in many studies and also confirmed in this study $[9,22,30]$. Lower amount if this element in the diet was noted by Catyniuk et al. [4], but even there its intake was by ca. $33 \%$ higher than recommended. Too high consumption of phosphorus can lower the absorption of calcium, magnesium, iron, zinc and disrupt appropriate ratio of calcium to phosphorus, which in turn can lead to higher risk of osteoporosis [18].

The content of magnesium is often insufficient in the diets of the elderly. The norm on this element in this study was realized at the level of $84.6 \%$ in the diets of $\mathrm{NH}$ residents and $89.6 \%$ in the diets of DP citizens. In the study of Pieter [22] the supply of magnesium covered on average $88.5 \%$ of required amount. Other authors also confirmed too low content of this element in the diets of the elderly $[25,30]$. Deficiency in magnesium leads to circulatory failure, arrhythmia, anaemia and may affect the development of atherosclerosis and osteoporosis in women after the menopause. Moreover, too high consumption of sodium increases the secretion of magnesium from the organism [22].

An excessive supply of iron was determined in the DFRs of the examined people, and it amounted to $12.1 \mathrm{mg}$ in case of the residents of $\mathrm{NH}$, which was significantly higher in comparison to that of the citizens of DP $(9.9 \mathrm{mg})$ - that corresponded to $201.3 \%$ ad $165 \%$ of the norm, respectively. The results of the studies performed among the participants at the age above 65 taking part in PolSenior project were similar to those in this study. It was shown that the consumption of iron in this age group exceeded recommended values by ca. $68 \%$ [17]. A slightly lower intake of this element was noted by Pieter [22] and Gacek [9]. Other conclusions were drawn by Kowalczuk-Vasilev and Klebaniuk [14], who showed that the content of iron in the diets of the residents of $\mathrm{NH}$ in Lublin was too low and covered only $88.4 \%$ of recommended intake. Too high supply of iron increases the production of free radicals in the organism, which can result in higher risk of carcinogenesis and coronary disease [6].

This study showed that the consumption of zinc was at appropriate level, both in case of elderly people living in $\mathrm{NH}$ and in family homes. However, $\mathrm{NH}$ diets contained significantly more zinc than home diets. Obtained results are comparable to those presented in the study PolSenior [17], where the average demand on this component was realized in $112.5 \%$. Different results were obtained by Wtodarek and Gtabska [30], who noted that average consumption of zinc was by almost $10 \%$ higher than recommended. Insufficient intake of this element in diets of the elderly can contribute to the lack of appetite through distortion of taste and smell, and may also decrease the activity of immune system and impair cognitive functions [7]. 
In this study an excessive intake of copper was observed. Its consumption exceeded recommended levels by $52.2 \%$ in case of the residents of $\mathrm{NH}$ and by $37.8 \%$ in case of DP citizens. Excessive amount of copper was also noted in diets of NH in Warsaw, where the average intake was almost twice higher than recommended [30].

Too high consumption of vitamin A was observed in the diets of the two examined groups. DFRs of the residents of NH supplied on average $1429.1 \mu \mathrm{g}$ of vitamin A (252.6\% of the norm) whereas DFRs of DR citizens - $852.4 \mu \mathrm{g}$ (157.7\%). Obtained results were similar to those in other studies, where a higher intake of this vitamin was reported [9, 14, 22, 30], especially in case of the people living in NH.

Vitamin $E$ as a strong antioxidant can prevent aging and carcinogenesis [22]. This study showed that both groups consumed insufficient amounts of tocopherol, whose amount was significantly lower in the diets of the residents of $\mathrm{NH}$ and amounted to $5.86 \mu \mathrm{g}$, i.e. the norm was realized in $65 \%$. Too low intake of vitamin E with the diet was also reported by Całyniuk et al. [4], who observed that DFRs of citizens of Silesia aged above 65 realized the norm at the level of ca. $66 \%$. Diets of NH residents in Kraków also contained insufficient amount of this component (68.8-83.8\% of the norm) [24]. However, Gacek [9] noted that nursing home residents in Cracow consumed too much vitamin $\mathrm{E}$, realizing the norm in $137.6 \%$.

Performed analyses showed alarmingly low consumption of vitamin $\mathrm{D}$, which for $\mathrm{NH}$ residents was at the level of $2.5 \mu \mathrm{g} /$ day (16.6\% of the norm). Diets of the citizens of DP supplied even less of this vitamin - on average $2.2 \mu \mathrm{g} /$ day, i.e. $14.9 \%$ of the norm. Other authors also showed insufficient intake of this component with the diet - the requirements were covered in $13-23 \%[18,22,23,27]$.

The analysis of the contents of group B vitamins showed correct or extensive intake in both groups irrespectively of the place of residence. Diets of $\mathrm{NH}$ residents were too abundant in vitamins $\mathrm{B}_{12}$ and $\mathrm{B}_{2}$, and to a lesser degree in vitamin $\mathrm{B}_{6}$ and niacin. DP citizens consumed too much niacin and vitamin $\mathrm{B}_{6}$. Obtained results are in contradiction with the data reported by other researchers. Całyniuk et al. [4] observed too low consumption of group B vitamins. The analysis of the menus from $\mathrm{NH}$ in Lublin also showed insufficient coverage of the demand on vitamin $\mathrm{B}_{1}(71.7 \%)$ and $\mathrm{B}_{2}(55.3 \%)$ [14]. However, in studies in the $\mathrm{NH}$ in Cracow, the correct amounts of vitamins $\mathrm{B}_{1}$ and $\mathrm{B}_{2}$ and too high content of vitamin $\mathrm{B}_{12}$ were noted [30].

The demand on folates was not covered in DFRs of both groups - the norm was realized in $44 \%$ in case of NH residents and in 79\% in case of DP citizens. The results of this study correlate with those obtained by other authors $[18,25,27,30]$.
The consumption of vitamin $\mathrm{C}$ varied among the examined people. The people living in $\mathrm{NH}$ consumed significantly less vitamin ( $47.4 \%$ of the norm) than the citizens of DP (158.7\%). It should be noted that high doses of ascorbic acid are not harmful to the organism due to little bioavailability and secretion with urine. However, in some persons its excessive amount may lead to the formation of kidney stones [22]. In the study of Różańska et al. [25] the average supply of vitamin $\mathrm{C}$ was realized in $78.5 \%$. On the other hand, Pieter [22] reported too high intake of ascorbic acid in DFR (ca. 283\%). Such discrepancies may be caused by seasonal availability of this vitamin.

Obtained results indicated nutritional errors, which were reflected in the amount of particular nutrients in the diets of the elderly. Due to multiple morbidities often occurring in this age group a special attention should be paid to proper composition of the menus. This can be facilitated by the presence of qualified personnel in nursing homes and food education available for elderly people.

\section{CONCLUSIONS}

1. The obtained results indicate a lack of DFR's balance of both groups which could contribute to improper nutritional status of the examined people.

2. The daily food rations of the subjects were characterized by a high content of sodium and protein as well as low potassium which may disturb the functioning of the cardiovascular system.

3. The diets of both groups had too low amount of calcium, magnesium, vitamin $\mathrm{D}$ and too high content of phosphorus, which may increase the risk of osteoporosis.

4. Due to the irregularities in DFR it is justifiable to introduce food education for elderly people and the personnel in the audited Nursing Home in Żabów, on the prevention of diseases associated with older people.

5. The irregularities in the analyzed diets do not differ significantly from the diet of older people stated by other research centers in the country.

\section{Conflict of interest}

The authors declare no conflict of interest.

\section{REFERENCES}

1. Babiarczyk B.: Monitorowanie stanu odżywienia osób starszych hospitalizowanych na oddziałach oraz w zakładach opieki krótko- i długoterminowej. [Monitoring of nutritional status in elderly short- and long-term careresidents]. Gerontol Pol 2008;16(1):1824 (in Polish). 
2. Bulska J.: Zagrożenia zdrowia chorobami cywilizacyjnymi. Pedagogiczne konteksty badawcze. [Health risks of civilization diseases. Pedagogical research contexts]. Kraków: Wyd. Impuls, 2008 (in Polish).

3. Całyniuk B., Muc-Wierzgoń M., Niedworok E., Dul L., Bielaszka A., Kardas M., Kiciak A., Szczepańska E.: Sposób żywienia osób po 65. roku życia zamieszkałych na terenie wybranych miast Śląska. Cz. I. Zawartość energii i podstawowych składników pokarmowych w diecie. [Nutritional habits of persons over the age of 65 residing at selected towns of the Silesian Region. Part I. Contents of energy and basic nutrients in diet] Żyw Człow Metabol 2008;35(4):289-300 (in Polish).

4. Całyniuk B., Muc-Wierzgoń M., Niedworok E., Dul L., Bielaszka A., Kardas M., Kiciak A., Szczepańska E.: Sposób żywienia osób po 65. roku życia zamieszkałych na terenie wybranych miast Śląska. Cz. II. Zawartość wybranych witamin i składników mineralnych w diecie. [Nutritional habits of persons over the age of 65 residing at selected towns of the Silesian Region. Part II. Content of selected vitamins and minerals in diet]. Żyw Człow Metabol 2009;36(3):548-560 (in Polish).

5. Duda G., Wichura-Demska A.: Wpływ wybranych czynników socjodemograficznych na poziom wiedzy osób zdrowych dotyczącej racjonalnego żywienia [Influence of selected socio-demographic factors on the knowledge level of proper nutrition rules' in the group of healthy individuals]. Nowiny Lek 2008;77(4):290293 (in Polish).

6. EFSA Panel on Dietetic Products, Nutrition and Allergies (NDA). Scientific opinion on dietary reference values for iron. EFSA Journal 2015;13, 10, 4254.

7. EFSA Panel on Dietetic Products, Nutrition and Allergies (NDA). Scientific opinion on dietary reference values for zink. EFSA Journal 2014;12, 10, 3844.

8. Ene-Margit T., Kai S.: Body mass index of elderly Europeans. Papers on Anthropology 2015;24(2):114-128.

9. Gacek M.: Zawartość energii i składników odżywczych w planowanych do spożycia racjach pokarmowych mieszkańców Domu Pomocy Społecznej w Krakowie [Energy and nutrients content in planned for consumption dietary rations of old people's home dwellers in Cracov]. Rocz Panstw Zakl Hig 2010;61,2:207-212 (in Polish).

10. Global Strategy on Diet, Physical Activity and Health (2004). World Health Organization. Available at: www.who.int/dietphysicalactivity/strategy/eb11344/ strategy english web.pdf (Accessed 01.02.2019).

11. Grochowska-Niedworok W., Catyniuk B., Szczepańska E., Muc-Wierzgoń M., Dul L., Kiciak A., Bielaszka A., Kardas M., Stolarczyk A.: Wartość energetyczna i odżywcza diety osób po 65 roku życia, zamieszkałych w domach pomocy społecznej na terenie Śląska. [Contents of energy and basic nutrients in diet of persons older than 65 living in Welfare Centers in Silesia]. Ann Acad Med. Siles 2012;66,5:9-14 (in Polish).

12. GUS: Sytuacja demograficzna osób starszych i konsekwencje starzenia się ludności Polski w świetle prognozy na lata 2014-2050. [Demographicsituation of elderly people and the consequences of ageing in
Poland in the view of the prognosis for the years 2014 2050], Warszawa 2014 (in Polish).

13. Jarosz M.: Normy żywienia dla populacji polskiej. [Nutrient requirements for Polish population]. Wyd. IŻŻ, Warszawa, 2017 (in Polish).

14. Kowalczuk-Vasilev E., Klebaniuk R.: Preferencje żywieniowe osób powyżej 50-tego roku życia z uwzględnieniem wybranych schorzeń. [The nourishment preferences of people over 50 years old, in respect of some diseases]. Żyw Człow Metabol 2009;36,2:278-286 (in Polish).

15. Kulik T.B., Janiszewska M., Piróg E., Pacian A., Stefanowicz A., Żotnierczuk-Kieliszek D., Pacian J.: Sytuacja zdrowotna osób starszych w Polsce i innych krajach europejskich. [Health situation of the elderly in Poland and other European countries]. MONZ 2011;17(2):90-95 (in Polish).

16. Leszczyńska T., Sikora E., Bieżanowska-Kopeć R., Pysz K., Nowacka E.: Ocena prawidłowości bilansowania składu racji pokarmowych osób starszych zamieszkujących w wybranych domach pomocy społecznej oraz w zakładzie opiekuńczo-leczniczym. [Evaluating the correctness of balancing the daily diets of the elderly living in the selected residential care homes and in a nursing house]. Żywn Nauka Technol Jakość 2008;2,57:140-154 (in Polish).

17. Madej D., Borowska K, Bylinowska J., SzybalskaA., Pietruszka B.:Dietary intakes of iron and zinc assessed in a selected group of the elderly: are they adequate? Rocz Panstw Zakl Hig 2013;64,2:97-104.

18. Malczyk E., Zołoteńska-Synowiec M., Catyniuk B., Guzik $W$.: Ocena sposobu żywienia osób po 60. roku życia pochodzących z Jodłowa i Nadziejowa [The Assessment of Nutrition of People over 60 Years of Age from Jodłów and Nadziejów]. Piel Zdr Publ 2014;4,3:219-226 (in Polish).

19. Markiewicz R., Socha K., Borawska M.H., Gutowska A.: Cynk i miedź w dietach pensjonariuszy z Domu Pomocy Społecznej w Białymstoku [Zinc and copper in diets of people living in the social nursing home in Białystok]. Rocz Panstw Zakl Hig 2008;59,4:415-420.

20. NEMO team. A consensus document from Dietitian/ Nutritionists from the Nutrition Education Materials Online, 2014. Available at: https:/www.health.qld. gov.au/_data/assets/pdf_file/0031/147937/hphe_ usingbmi.pdf (Accessed 02.02.2019)

21. Orkusz A., Gorla B.: Ocena sposobu żywienia mieszkańców domu pomocy społecznej na terenie województwa dolnośląskiego. [Assessment of Nutrition of the Nursing Home Residents in lower Silesia]. Nauki Inż. Technolog 2016;3,22:51-62 (in Polish).

22. Pieter E.: Ocena spożycia witamin i składników mineralnych przez osoby po 60 roku życia. [Vitamins and Minerals Intake in the Diet of People Over 60 Years of Age]. Piel Zdr Publ 2014;4,3:209-217 (in Polish).

23. Pudełko A., Nowak J.: Ocena jadłospisów dekadowych realizowanych w wybranych Domach Pomocy Społecznej na terenie Śląska w aspekcie zawartości witaminy D i wapnia [Assess of the 10-day diet plans at selected nursing homes located in the Silesian province 
of Poland, in the aspect of vitamin D and calcium content]. Geriatria 2016;10:240-247 (in Polish).

24. Pysz-Izdebska K., Leszczyńska T., Kopeć A., Nowacka E., Bugaj B.: Pokrycie zapotrzebowania na energię i wybrane składniki odżywcze w diecie pensjonariuszy domu pomocy społecznej oraz ocena ich parametrów antropometrycznych. [Meeting the demand for energy and selected nutritients in diets of residents of one selected residential care home for adults and evaluation of their anthropometric parameters]. Żywn Nauka Technol Jakość 2010;6,73:239-254 (in Polish).

25. Różańska D., Wyka J., Biernat J.: Sposób żywienia ludzi starszych mieszkających w małym mieście Twardogórze. [Food intake of elderly inhabitants of a small town - Twardogora]. Probl Hig Epodemiol 2013;94,3:494-502 (in Polish).

26. Suliga E.: Zachowania zdrowotne związane z żywieniem osób dorosłych i starszych [Health behaviours related to the nutrition of adults and elderly people]. Hygeia Public Health 2010;45,1:44-48 (in Polish).

27. Sygnowska E., Waśkiewicz A.: Ocena sposobu żywienia osób w wieku 60-74 lat. Badanie Wobasz. [Estimation of nutritional habits of persons aged 60-74. Wobasz study]. Bromat Chem Toksykol 2011;44,3:240-244 (in Polish).
28. Szponar L., Wolnicka K., Rychlik E.: Album fotografii produktów i potraw [Photo album of products and dishes]. Warszawa, Wyd. IŻŻ, 2000 (in Polish).

29. Tańska M., Babicz-Zielińska E., Przysławski J.: Postawy osób starszych wobec zdrowia i żywności o działaniu prozdrowotnym [Attitudes of the elderly towards the issues of health and healthy food]. Probl Hig Epiemiol 2013;94,4:915-918 (in Polish)

30. Włodarek D., Głąbska D.: Ocena realizacji potrzeb żywieniowych starszych mężczyzn mieszkających we własnych domach i w domach opieki. [Assessment of the satisfaction of the nutritional needs of elderly men living independently and in nursing homes]. Geriatria 2013;7:195-202 (in Polish).

31. Wojszel Z.B.: Determinants of nutritional status of older people in long-term caresettings on the example of the nursing home in Białystok. Adv Med. Sci 2006;51:168-173.

32. Zołoteńka-Synowiec M.E., Malczyk E., Całyniuk B., Grzesik I., Hajuga M., Oknińska E.: Ocena stanu odżywienia i składu ciała osób starszych pensjonariuszy domów pomocyspołecznej i Dziennego Domu Pobytu w Nysie. [Assessment of nutritional status and body composition of elderly people living in nursing homes and a day-carecenter in Nysa, Poland]. Piel Zdr Publ 2018;8(4):245-251 (in Polish).

Received: 28.02.2019

Accepted: 26.04.2019 